( О. В. Зоренко, канд. техн. наук, доц., О. Б. Стефанишена, магістр, Р. А. Хохлова, канд. техн. наук, доц., Є. В. Штефан, д-р техн. наук, проф., КПІ ім. Ігоря Сікорського, Київ, Україна

\title{
ТРИБОЛОГІЧНИЙ АНАЛІЗ СИСТЕМИ «ДРУКАРСЬКА ФОРМА ГЛИБОКОГО МЕТОДУ ДРУКУ-ВІДБИТОК»
}

Розглянуто тенденції виготовлення гнучких паковань з полімерних матеріалів глибоким методом. Проаналізовано зону друкарського контакту глибокого методу друку з позицій трибології, вплив елементів триботехнічної системи та їх властивостей на зносостійкість друкарської форми і якість тиражних відбитків. Розроблено класифікації формних матеріалів, формного обладнання глибокого методу друку, триботехнічну модель взаємодії елементів системи “друкарська форма глибокого друку-відбиток", алгоритм формного процесу та рекомендації з підвищення тиражостійкості друкарських форм глибокого методу друку.

Ключові слова: глибокий метод друку; гнучке паковання; тиражостійкість друкарської форми; триботехнічна система; трибологічний аналіз.

Постановка проблеми

Тенденції розвитку світової видавничо-поліграфічної галузі в умовах пандемії вірусу COVID-19 до 2025 р., свідчать про зростання сегменту друку на пакованні (через збільшення населення, підвищення рівня урбанізації та збільшення потреби в екологічному пакованні). Зокрема, прогнозується значний ріст обсягу виробництва на гнучких задруковуваних матеріалах (різні види полімерних плівкових матеріалів, фольги), при цьому частка цього виду поліграфічної продукції в загальному об'ємі поліграфічного ринку (\$468 млрд) в 2020 р. складала \$157 млрд [1, 2], а до 2025 р. його об'єм сягне $\$ 314,98$ млрд із середньорічним ростом у 2020 2025 рр. в 3,87\% [3]. Світове виробництво гнучкого паковання з 2007 р. зросло майже на 50\%, а в Європі його споживання збільшилось близько на 30\% [4], що стало можливим завдяки ключовим перевагам порівняно з іншими видами (картонне, скляне, металеве), а саме меншій масі, енерговитратам необхідним для формування паковання, зручності транспортування, можливості створення оптимальних бар'єр- 
них властивостей завдяки поєднанню у складі паковання різних матеріалів (плівок, фольги, паперу) тощо.

За прогнозами до 2022 року [5] серед використовуваних методів друку гнучких паковань, які матимуть тенденцію до зростання до 15,4 \% [2] є цифрові технології. Проте лідерами залишатимуться флексографічний та глибокий методи завдяки технікотехнологічним особливостям процесів виготовлення, тиражній якості та собівартості друкованої продукції.

Пріоритетні параметри глибокого методу друку, такі як якість та швидкість друку, кольоровідтворення друкованих відбитків, тиражостійкість друкарських форм (ДФ), яка є їх головною друкарсько-експлуатаційною характеристикою, впливають на стабільність та якість друкування накладу. Зокрема, висока тиражостійкість ДФ дозволяє підвищити коефіцієнт використання друкарських машин, зробити більш стабільним процес виготовлення тиражних відбитків та підвищити їх якість, а також завдяки зменшенню кількості форм, знизити собівартість друкованої продукції [6].

Зважаючи на вищезазначені сучасні напрями розвитку поліграфічного ринку гнучких паковань з полімерних плівок, актуальним $\epsilon$ дослідження чинників формного та друкарського процесів, що зокрема, впливають на тиражостійкість ДФ та в цілому на якість виготовлення паковальної продукції глибоким методом друку.

\section{Аналіз попередніх досліджень}

Разом з вищеперерахованими перевагами глибокого друку йому характерні й недоліки, пов'язані з формними процесами (які є вартісними і довготривалими порівняно, зокрема, з флексографічним методом друку), які стримують його поширення в світі та ускладнюють конкуренцію з іншими методами друку. ДФ глибокого методу друку являють собою циліндри багатошарової структури, сформованої за допомогою гальванічного покриття з міді чи цинку. Циліндр-основа виготовляється переважно зі сталі, але також для зменшення ціни та маси ДФ може використовуватись алюміній чи пластмаси (рис. 1). Спеціальні пластмаси, композиційні матеріали на основі вуглеводного полотна - це сучасні розробки, над якими ще проводяться роботи та дослідження з їх удосконалення [7, 8]. Циліндр-основа повинна мати високу жорсткість та забезпечува-

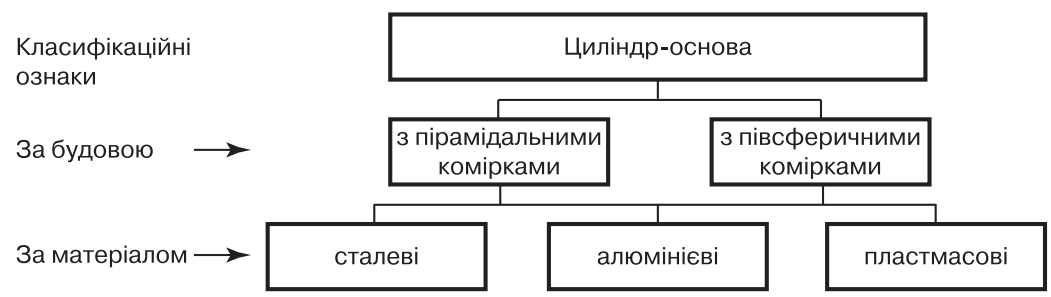

Рис. 1. Класифікація циліндрів-основ ДФ глибокого друку 
ти мінімальний прогин, довгі циліндри повинні мати більшу структурну жорсткість. Тому алюмінієві та пластмасові основи доцільно використовувати лише при вузькорулонному друці. Ці процеси вимагають спеціального обладнання та додаткових матеріалів, а якість нанесення кожного гальванічного покриття впливає на якість нанесення наступного, а також безпосередньо впливає на якість виготовлення ДФ та тиражну якість відбитків.

Як матеріал для створення робочої поверхні ДФ використовується мідь. Оскільки сталева поверхня не утримує мідне покриття, то на неї наносять тонкий шар нікелю (товщина 1-3 нм), який підвищує зв'язок між сталлю та міддю. Далі наносяться основний шар міді (товщина 1-2 мм), срібломісткий бар'єрний шар та робочий шар міді товщиною 80 нм (за методом Балларда) або лише робочий шар міді (за методом тонкого та товстого шару). Перед нанесенням кожного нового шару поверхня циліндру знежирюється і з неї видаляється оксидна плівка за допомогою розбавленого розчину сірчаної кислоти. Після нанесення кож- ного шару поверхня циліндру також обробляється: шліфується та/чи полірується.

Залежно від рівня занурення ФЦ в електроліт гальванічні ванни поділяються на ванни з повним (на $90 \%$ ) та частковим (на $75 \%$ ) зануренням, останні найбільш використовувані завдяки пришвидшенню нанесення покриття (рис. 2).

Процес гальванопокриття складний і потребує контролю багатьох його параметрів: хімії електролітів, циркуляції електроліту, виходу по струму, ступеню занурення, густини струму, відстані анод/катод, температури тощо.

Запис зображення на ДФ глибокого друку можливий з використанням різних технологій: електромеханічного та лазерного гравіювання, маскової технології з наступним травленням мідного шару формного циліндра (рис. 3). Остання технологія поступово зникла із сучасних поліграфічних підприємств через свою високу шкідливість та поступилась більш раціональному запису методом гравіювання, зокрема лазерного, завдяки таким його перевагам як висока швидкість (70000 комірок/с);

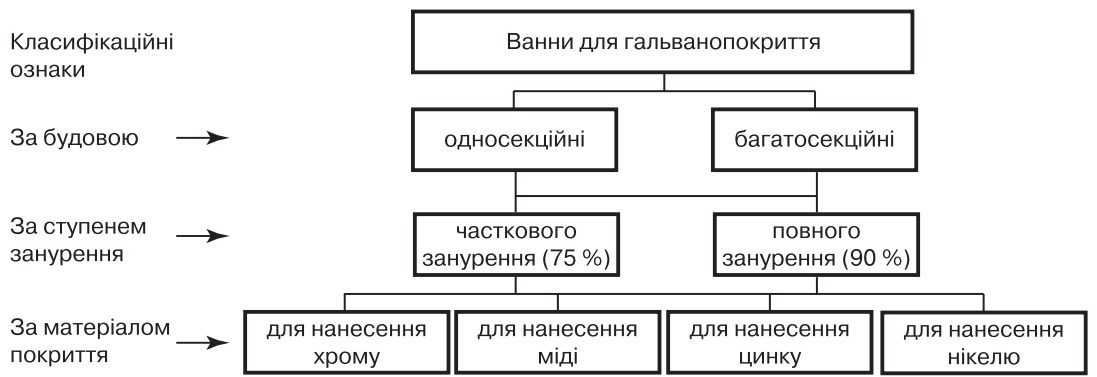

Рис. 2. Класифікація ван для гальванопокриття ДФ глибокого друку 


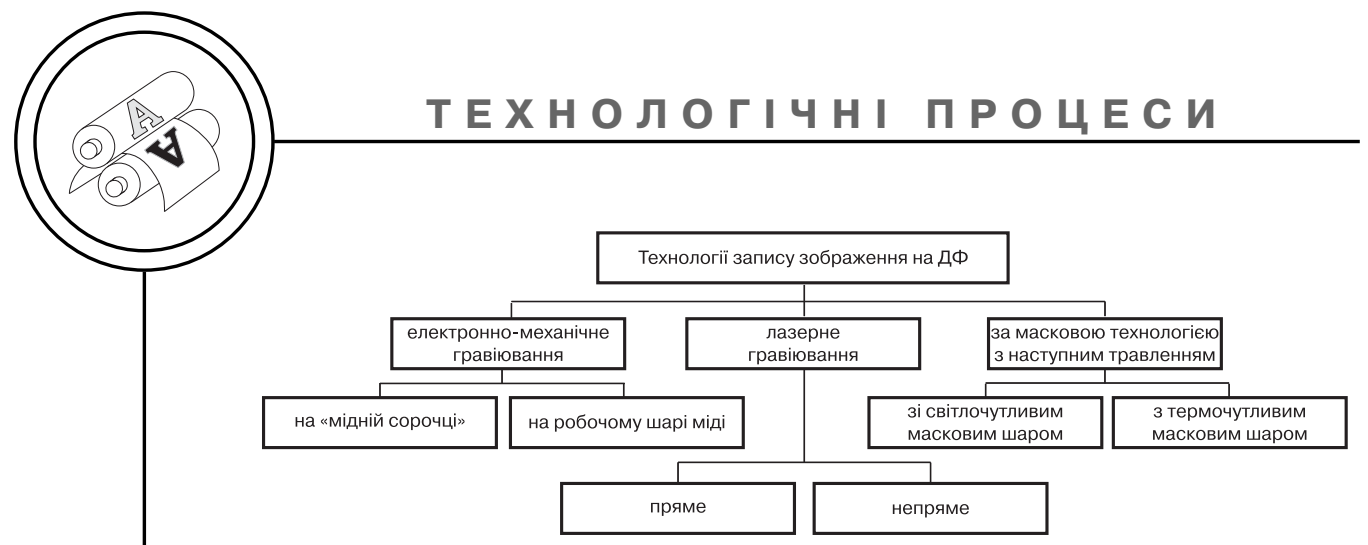

Рис. 3. Класифікація технологій запису зображення на ДФ глибокого друку

зменшення витрати фарби при друкуванні через півсферичну форму друкувального елементу/ комірки та регулюванню глибини і площі комірок; лазерне гравіювання $€$ безконтактним порівняно з ЕМГ, де алмазний різець постійно піддається зношенню через контакт з ДФ.

При застосуванні лазерного гравіювання матеріалом для робочого шару ДФ є цинк, який порівняно з міддю має меншу теплопровідність і відповідно не потребує надпотужних лазерів для гравіювання (теплопровідність цинку за $20^{\circ} \mathrm{C}=125,6 \mathrm{BT} / \mathrm{M} \mathrm{K}$, міді - 319,5 Вт/м К). Також на поверхню ДФ гальванічним методом наносять шар хрому, завдяки якому твердість ДФ складає 1100 HV, а також підвищується тиражостійкість та стійкість до постійного тертя ракеля $[9,10]$.
Виробники поліграфічного обладнання для виготовлення ДФ глибокого друку пропонують автоматизовані лінії з гальванованнами, формовивідними та пристроями для механічної обробки ітранспортерами (рис. 4), що також сприяє інтенсифікації технологічних етапів виготовлення ДФ.

Для друку на пакованні більш доцільно використовувати рулонні ротаційні друкарські машини (ДМ), адже вони забезпечують вищу швидкість друку і з віддрукованого рулону в подальшому буде легше формувати паковання. ДМ глибокого друку має лінійну будову, складається з рулонної зарядки, друкарських секцій (в кожній секції розміщена сушарка), пристрою для намотування полотна, при друкуванні на плівках обов'язковою є наявність секції активування коронним розрядом, сис-

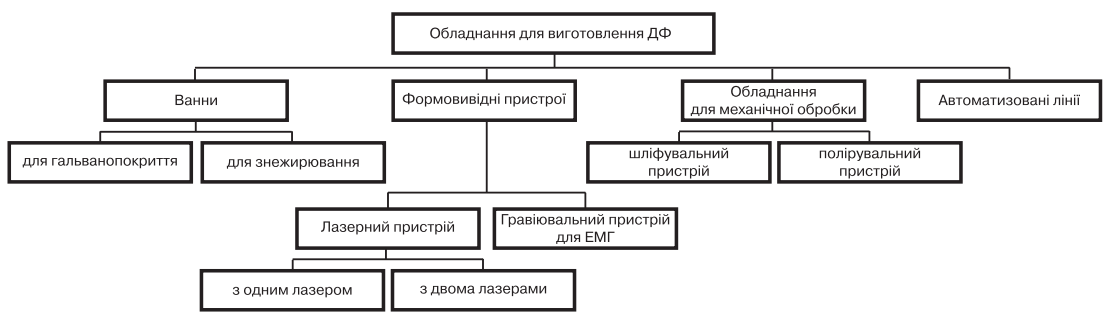

Рис. 4. Класифікація обладнання для виготовлення ДФ глибокого друку 
тем автоматичного вирівнювання та контролю натягу, моніторів, оптичних та електронних системам контролю якості друку $[11,12]$.

Враховуючи вищенаведені матеріали, методи та засоби для виготовлення ДФ глибокого способу, розроблено їх класифікацію (рис. 5).

\section{Мета роботи}

Визначити вплив чинників формного та друкарського процесів на друкарсько-експлуатаційні показники друкарських форм та тиражну якість відбитків задля оптимізації технології виготовлення якісної паковальної продукції глибоким методом друку.

\section{Результати проведених досліджень}

Друкарські форми глибокого друку являють собою циліндри, довжина яких може досягати 3,5 м. Для друкування гнучкого паковання використовуються циліндри довжиною 1200 мм. Формний циліндр складається зі стальної основи, тонкого шару нікелю (товщина 1-3 мкм), основного шару міді (товщина до 2 мм), розділювального срібломісткого шару (до 1 мкм), робочого шару міді чи цинку (товщина 80 мкм). Мікротвердість, завдяки нанесенню шару хрому, складає 1100 HV, а тиражостійкість сягає 1 млн відбитків; шорсткість поверхні $\left(\mathrm{R}_{\mathrm{z}}\right)$ лежить в діапазоні 0,3-0,5 мкм; форма комірок друкувальних елементів може бути різноманітною: ромбовидною (при ЕМГ), круглою, шестикутною, п'ятикутною тощо, глибина комірок варіюється від 6 до 80 мікрон [10].

Тиражостійкість ДФ - можливість продукування з неї макси-

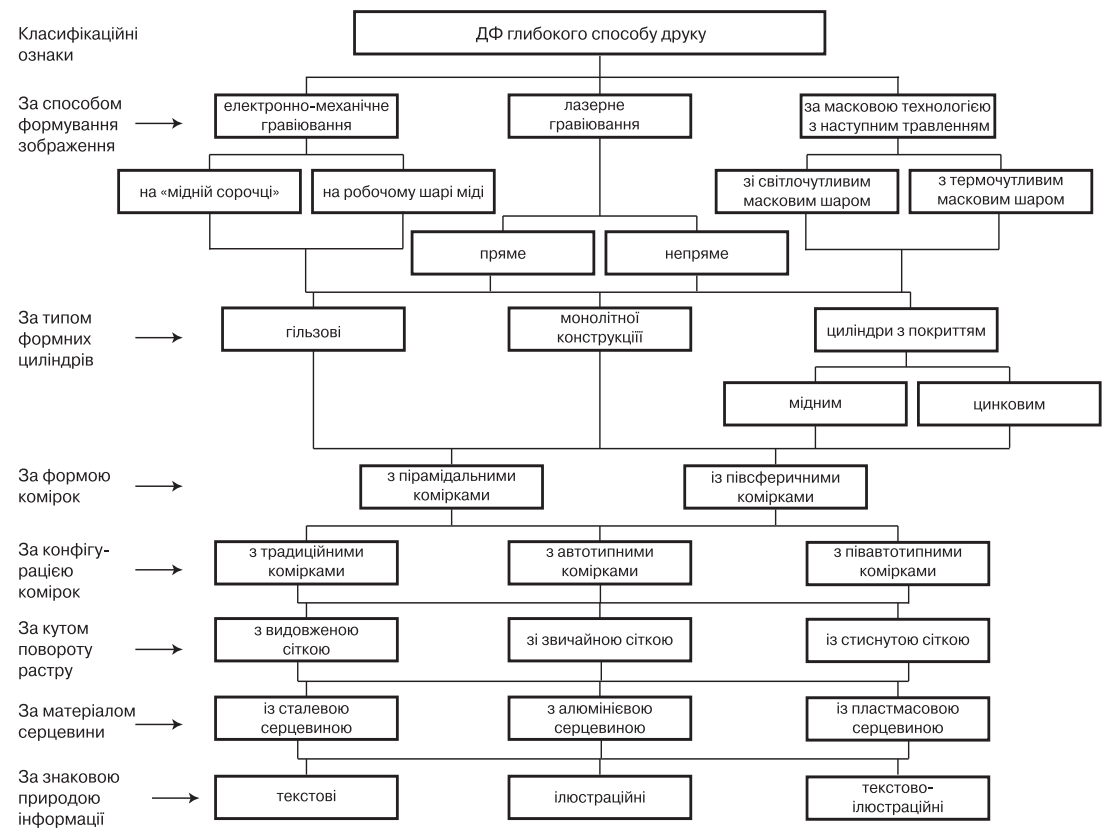

Рис. 5. Класифікація ДФ глибокого друку 
мальної кількості ідентичних відбитків, вона є основною друкарсько-експлуатаційною характеристикою, що впливає на стабільність та якість друку всього накладу. Тиражостійкість залежить від багатьох чинників формного та друкарського процесів: характеру відтворюваного зображення; методів, засобів та режимів виготовлення ДФ (у глибокому методі формних циліндрів), режимів процесу друкування (величина тиску, швидкість друку, кількість фарби, параметри ракеля); якості застосовуваних витратних поліграфічних матеріалів; технічного стану та налагодження друкарського, фарбового апаратів ДМ; кваліфікації працівників формної та друкарської ділянок; умов навколишнього середовища $[10,13,14]$.

У результаті зношення ДФ в глибокому друці погіршуються репродукційно-графічні параметри відбитків: роздільна та видільна здатності, градаційна передача; спостерігається поява дефектів «полошіння», розрив растрових опорних ліній, розпливання і видавлювання фарби за межі друкувальних елементів. Для забезпечення характерної для глибокого друку високої тиражостійкості форм потрібно контролювати багато чинників на всіх етапах виробництва. У процесі зношування ДФ зменшення глибини друкувальних елементів призводить до зменшення товщини фарбового шару на відбитку. Комірки зменшуються в об'ємі, що призводить до зниження фарбосприйняття та фарбоперенесення на задруковуваний матеріал.

Оцінку стабільності формного та друкарського процесу здійсню- ють за допомогою інструментального та візуального контролю якості тиражного відбитка за одиничними показниками якості друкованого зображення, чисельні значення яких вносяться у нормативні документи. Але на практиці на формній та друкарській виробничих ділянках спостерігається недотримання цих нормативних документів через відсутність єдиного автоматизованого технологічного комплексу, що містить формне та друкарське обладнання, витратні матеріали та контрольно-вимірювальну техніку [15].

Враховуючи вищезазначені чинники впливу на тиражостійкість ДФ глибокого друку, розроблено іх класифікаційну схему (рис. 6).

Згідно з рис. 6 основними чинниками впливу на формній ділянці є властивості ДФ (будова друкувальних та пробільних елементів, фізико-механічні параметри поверхні ДФ та її стійкість до розчинників фарб); режими нанесення гальванопокриття на формний циліндр, гравіювання ДФ; на друкарській ділянці: якість та відповідність витратних матеріалів (задруковуваний матеріал (папір, плівка, картон), друкарська фарба; ракель (конструкція, матеріал, кут загострення та встановлення)), технологічні режими процесу друку (кількість фарби, тиск в зоні друкарського контакту, швидкість); дефекти друкарського апарату (зношення підшипників формного і друкарського циліндрів); умови зберігання та транспортування ДФ, параметри навколишнього середовища (температура, вологість, пил) $[6,10,13,15,16]$.

Відповідно до технологічних особливостей проведення форм- 
ного процесу розроблено алгоритм технологічних етапів виготовлення друкарських форм з використанням лазерного гравіювання (рис. 7).

В процесі експлуатації ДФ контактує з ракелем, фарбою та ЗМ, причому ракель завдає найбільшого впливу на її тиражостійкість. Тому потрібно використовувати якісні ракелі з оптимальними характеристиками, підбирати кут загострення леза ножа (оптимальний 20-25 ), кут встановлення по відношенню до ДФ (залежить від характеру ДФ, властивостей фарби, кута гостроти ножа, його товщини тощо, коливається в межах від $15^{\circ}$ до $80^{\circ}$; причому збільшення кута загострення ракеля призводить до зниження еластичності ножа і погіршення однорідності зняття надлишків фарби; зменшення до зниження стійкості ножа проти дії твердих частин, які потрапляють у фарбу або привносяться ЗМ; при малому куті нахилу необхідно збільшити притискання ракеля до ДФ для повного зняття надлишку фарби з поверхні циліндра; при великому куті ракель добре знімає фарбу, але швидко зношується сам і зношує форму, пошкоджується твердими частинками, які знаходяться в фарбі, й швидше виходить з ладу та потребує чергового гостріння) та зусилля притиску (можливо ракель встановлювати під від'ємним

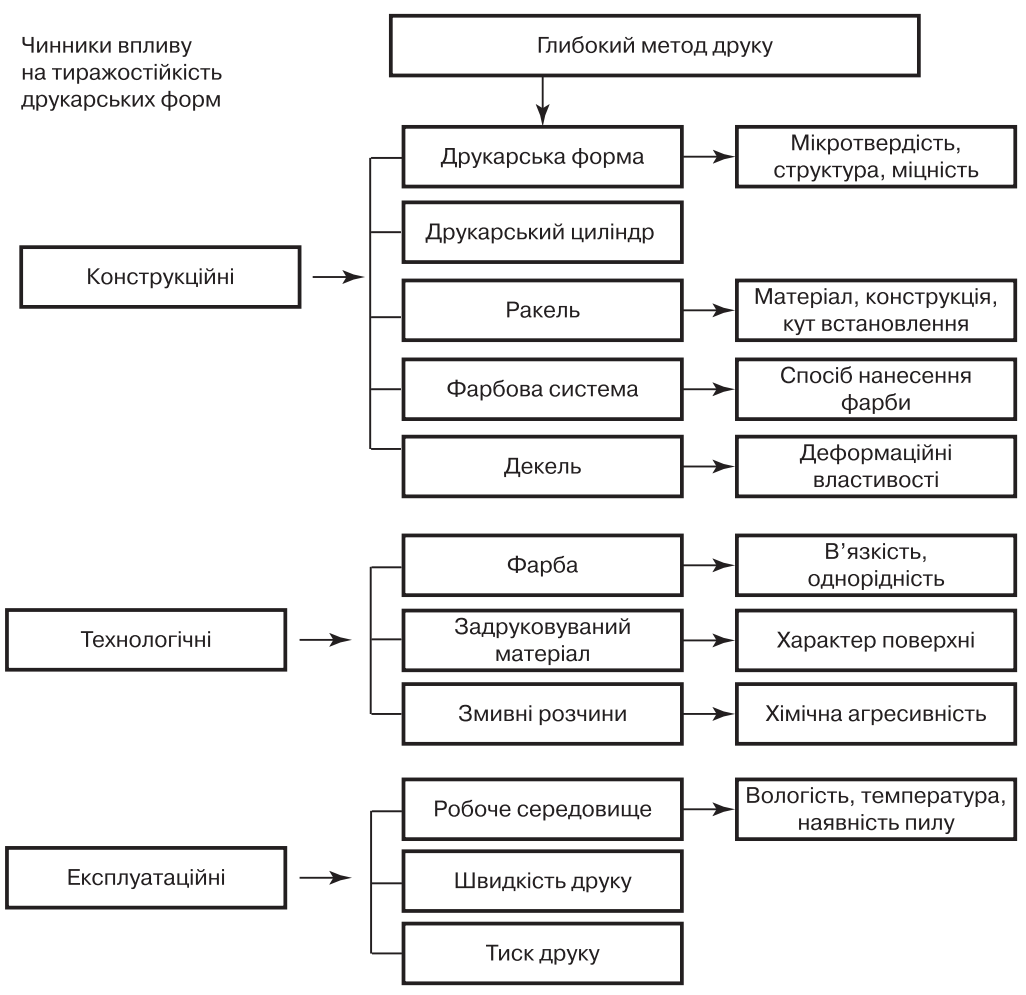

Рис. 6. Чинники впливу на тиражостійкість ДФ глибокого друку 
кутом - 140-150', що дозволяє приблизно в 10 разів зменшити необхідне зусилля притискання ножа до циліндра і підвищити тиражостійкість ДФ; також виключається заклинювання фарби під ракелем і зменшується вірогідність утворення подряпин на ДФ при потраплянні на неї твердих частинок).

Чинники впливу на роботу ракеля: гідродинамічний тиск фарби, що виникає в клиновому

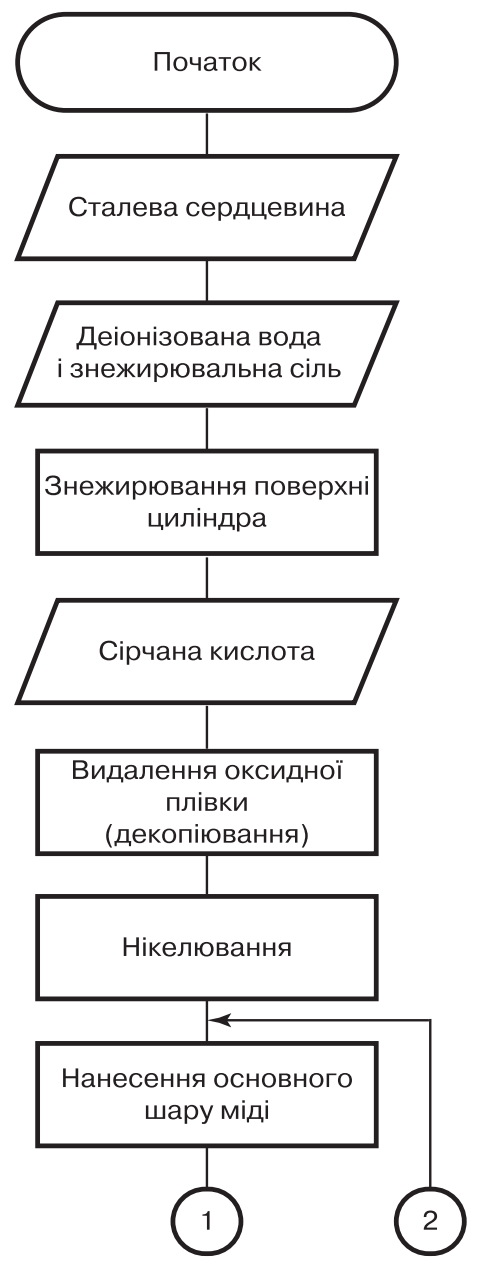

зазорі між ракелем та поверхнею ДФ. На його значення впливають швидкість друку (підвищення в два рази $(4,5 \ldots 9$ м/с) збільшує гідродинамічне навантаження на ракель у три-чотири рази), кут встановлення ракеля (збільшення від $45 \ldots 85^{\circ}$ зменшує гідродинамічний тиск у $5 \ldots 6,5$ разів); зусилля притиснення ракеля до ДФ - для компенсування впливу гідродинамічного тиску, неточності геометричної форми

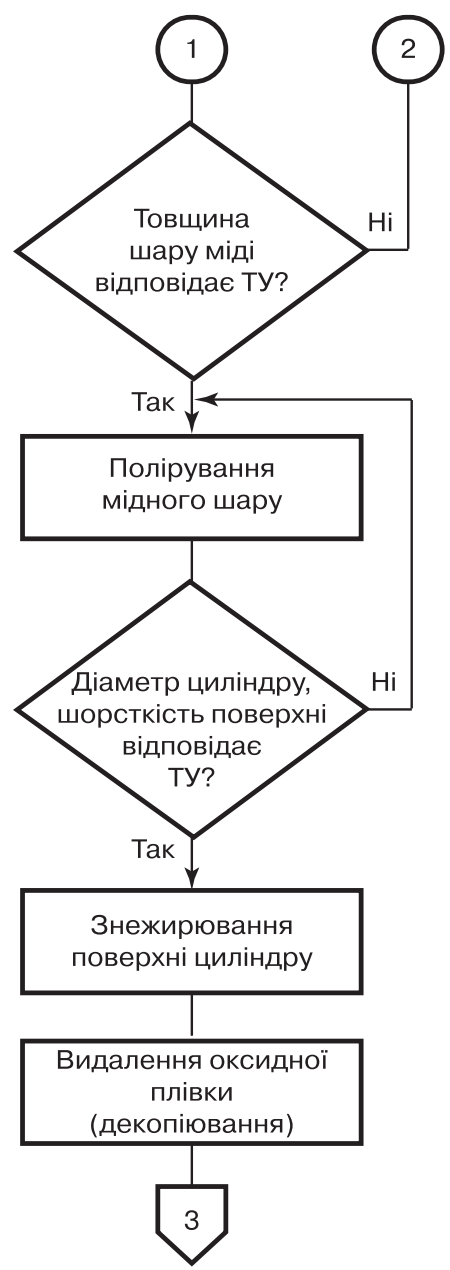

Рис. 7. Алгоритм виготовлення ДФ глибокого друку. Початок 
та биття ФЦ при обертанні. На зусилля впливає кут встановлення ракеля (збільшення призводить до прогинання ракеля, зростання зусилля притиснення до ДФ) [10].

Фарби глибокого друку потрібно підбирати високої якості з відсутністю домішок, перед здій- сненням друку підготовлювати їх в фарбовій системі ретельно розмішуючи. Потрібно в додрукарському, друкарському цеху та приміщенні, де зберігаються форми дотримуватись чистоти повітря та підтримувати оптимальні режими температури та вологості повітря. Високі вимоги

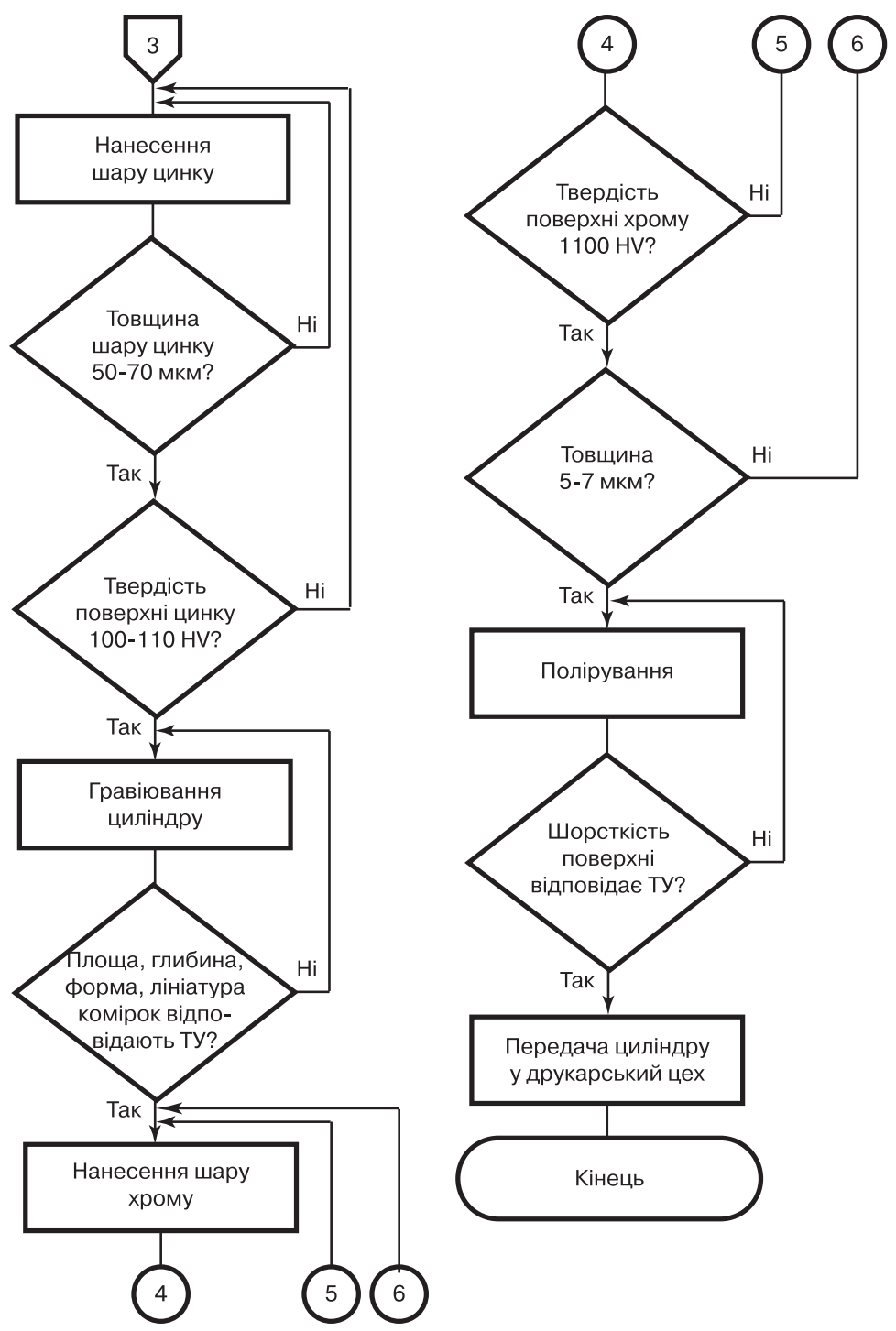

Рис. 7. Алгоритм виготовлення ДФ глибокого друку. Закінчення 
до якості друку та відтворення колірних характеристик на гнучкому пакованні, складність процесу виготовлення ДФ вимагають високої кваліфікації працівників.

Згідно трибологічного аналізу елементів, що входять у зону друкарського контакту глибокого методу розроблено триботехнічну модель взаємодії елементів системи «ДФ-відбиток» у глибокому друці (рис. 8).

Відповідно до положень трибології можна виділити такі періоди зміни параметрів друкарського контакту та тиражостійкості (зношення) ДФ: початковий (прироблення, припрацювання підготовка до друку), стабільного (перехід від початкового до сталого, що проходить з постійною швидкістю, характерною для даних умов - процес друкування тиражних відбитків) та прискореного (катастрофічного) зношення. Найбільш оптимальний для експлуатації ДФ - період стабільного зношення, за якого зміна якісних показників мінімальна. Тривалість даного періоду можна збільшити за рахунок застосування методів підвищення тиражостійкості, до яких відносяться такі: конструкційні (виготовлення і експлуатація ДФ із певними конструкційними, деформаційними і зносостійкими властивостями, оптимальне конструювання зони друкарського контакту, друкарського апарату; технологічні (оптимізація технології виготовлення ДФ та процесів підготовки друкарської машини до друку; експлуатаційні (зберігання/транспортування ДФ в оптимальних умовах між виробничими процесами, стабілізація процесу друку). Дані методи в свою чергу поділяються на керовані: технологічний процес виготовлення ДФ, швидкість та тиск процесу друкування, товщина фарбового шару на формі та відбитку); частково керовані: репродукційно-графічні та дру-

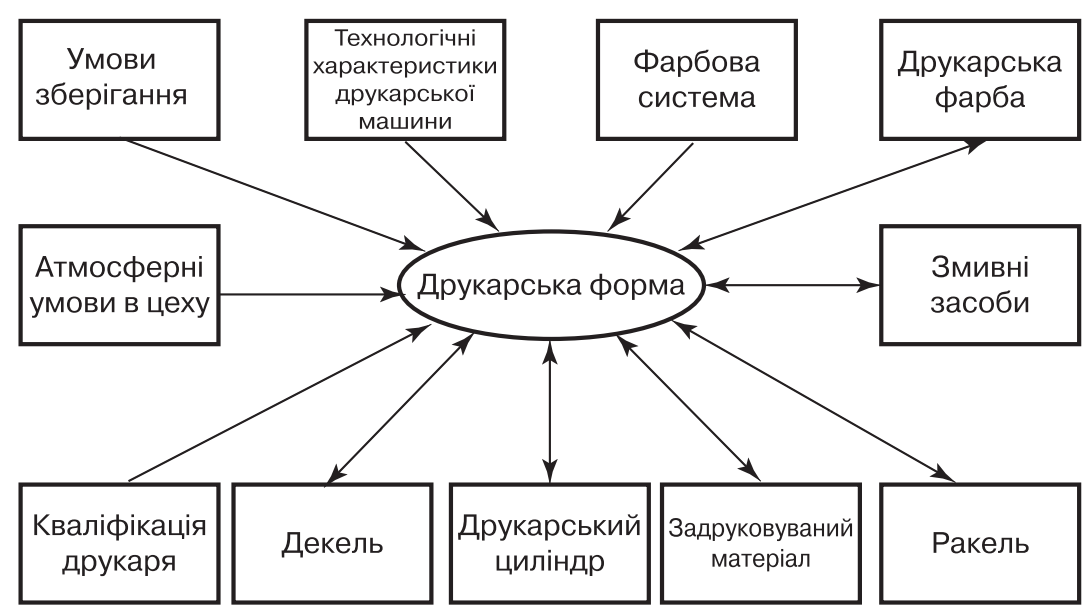

Рис. 8. Триботехнічна модель взаємодії елементів системи «Друкарська форма глибокого друку-відбиток» 
карсько-експлуатаційні показники формного матеріалу, регулювання яких дозволить підвищити тиражостійкість ДФ [13].

На друкарській ділянці запропоновано таку послідовність дослідження зміни тиражостійкості ДФ: отримання контрольних аркушів друкованих відбитків з кожного тиражного рулону друку та вимірювання оптичних густин на контрольному полі для оцінки градаційної передачі, видільної здатності та розрахунок відносних графічних спотворень штрихів, вимірювання параметрів комірок ДФ; оцінка якості тиражної друкованої продукції шляхом порівняння з еталонним відбитком та стану зношення ДФ відповідно до проведених вимірів; побудова контрольних карт за результатами вимірювання експериментальних даних визначених параметрів формного та друкарського процесу.

Контроль градаційної передачі здійснювати шляхом вимірювання оптичних густин на контрольному полі 3 растровими елементами різних відносних площ (5\%, $10 \%, 20 \%, 30 \%, 40 \%$, $50 \%, 60 \%, 70 \%, 80 \%, 90 \%$, $100 \%)$, дослідження відносних графічних спотворень штрихів визначати за вимірюванням товщини штрихів (75 мкм; 100 мкм; 125 мКм; 150 мКМ; 175 мКМ; 200 МКМ).

Для додаткової оцінки зношення ДФ досліджувати об'єм друкувальних елементів після друку накладу і порівнювати з їх об'ємом до друку. Величина об'єму комірки вимірюється для різних лініатур та при різному співвідношенні ширини перетинки до ширини комірки $(1: 2,1: 3,1: 4,1: 5,1: 6)$.
Для контролю параметрів друкарської форми використовуються програмно-апаратний комплекс наприклад, типу CheckMaster II (Heimann), що дозволяє вимірювати довжину, ширину, глибину і площу комірок та визначати їх об'єм. Здійснювати візуальну оцінку стану поверхні гальванопокриття (ії цілісність, відсутність механічних пошкоджень та дефектів), інструментальну оцінку поверхні шляхом вимірювання твердості та шорсткості.

\section{Висновки}

Розглянуто тенденції розвитку глибокого друку, зокрема, на гнучкому пакованні (найбільш використовувані методи друку, витратні матеріали, види та структура друкарських форм, формне устаткування).

Здійснено трибологічний аналіз зони друкарського контакту та розроблено модель взаємодії основних триботехнічних елементів системи «Друкарська формавідбиток».

Увиразнено чинники впливу на тиражостійкість ДФ глибокого друку та розроблено їх класифікацію. Визначено ступінь впливу зношування друкарської форми на якість друку (якість нанесення гальванопокриття при виготовленні ДФ, друкарськоексплуатаційні характеристики друкарських фарб, задруковуваного матеріалу, ракеля, режимні параметри формного та друкарського процесу).

Розроблено класифікаційні схеми ДФ, формного обладнання глибокого друку, алгоритм оптимального процесу виготовлення ДФ з використанням лазерного гравіювання. 


\section{Список використаної літератури}

1. Савченко К. І. Сучасний стан технологій друкування в Україні / К. І. Савченко, О. В. Зоренко, Т. В. Розум, О. М. Величко // Технологія і техніка друкарства. 2011. № 2(32). C. 21?27. DOI: http://doi.org/10.20535/20777264.2(32).2011.52761.

2. Н. Дубина. Главные тренды в упаковке: факты и прогнозы / Н. Дубина // КомпьАрт. 2019. № 2. [Електронний ресурс]. Режим доступу: http://compuart.ru/article/25411.

3. Гибкая упаковка: плюсов пока больше, чем минусов, соответственно, и рост неизбежен. 2020. [Електронний ресурс]. Режим доступу: http://printus.com.ua/article/read/4152.

4. Современные тенденции в гибкой упаковке. MacHouse. 2018. [Електронний ресурс]. Режим доступу: https://machouse.ua/press-center/s3/ publications/covremennye-tendentsii-v-hibkoj-upakovke.html.

5. Стефанишена О. Б. Сучасні тенденції розвитку глибокого друку / О. Б. Стефанишена, О.В.Зоренко // Технологія і техніка друкарства. 2020. № 3(69). C. 34-42. DOI: https://doi.org/10.20535/2077-7264.3(69).2020.224199.

6. Р. А. Хохлова. Відповідь поліграфії трендам розвитку упаковки // Упаковка. [Електронний ресурс]. Режим доступу: http://www.upakjour.com.ua/arx\%D1\%96v/ 2021/2-2021/pol\%D1\%96graf\%D1\%96ya/printing-answer.

7. Пат. 2018093467 США, МПК В41C1/18; B41F13/11; B41F9/00; B41N1/06; B41N1/20. Gravure cylinder and manufacturing method thereof / Sugawara Shintaro, Sato Yoshinobu; заявник і патентовласник Think Labs KK; заявл. 29.03.2016; опубл. 05.04.2018.

8. Пат. 2019171733 Японія, МПК В41C1/18; B41N1/16. Device for manufacturing resin coat gravure cylinder, method for manufacturing resin coat gravure cylinder and method for inspecting resin coat layer / Sawada Takashi, Morita Kosuke; заявник і патентовласник Toyo Ink SC Holdings Co LTD; Tоуо Ink Co LTD; заявл. 29.03.2018; опубл. 10.10.2019.

9. Самарин Ю. Во глубине печатных форм... / Ю. Самарин // КомпьюАрт. 2011. № 4. [Електронний ресурс]. Режим доступу: http://compuart.ru/article/22153.

10. Полянский Н. Н. Технология формних процессов: учеб. / Н. Н. Полянский, О. А. Карташева, Е. Б. Надирова. М.: МГУП, 2010. 366 с.

11. Современная технология и оборудование глубокой печати в производстве упаковочной продукции [Електронний ресурс]. Режим доступу: http://docplayer.ru/65181239-sovremennaya-tehnologiya-i-oborudovanieglubokoy-pechati-v-proizvodstve-upakovochnoy-produkcii.html.

12. Розум Т. В. Контроль якості друкування на пакованні / Т. В. Розум, Я. В. Зоренко, К. І. Савченко, В. М. Скиба // Упаковка. Журнал для виробників та споживачів тари і упаковки. 2012. № 3. С. 63-66. Режим доступу: http://pvs.uad.lviv.ua/static/media/1-57/15.pdf.

13. О. В. Зоренко. Декелі в офсетному друкарському процесі / О. В. Зоренко, О. Ф. Розум. Київ: ВПЦ «Київський університет», 2008. 168 с.

14. О. В. Зоренко. Зносостійкість офсетних гумотканинних полотнищ (вплив на тиражну якість відбитків) / О. В. Зоренко, А. П. Гавриш // Упаковка. 2008. № 4. C. $56-59$.

15. Скиба В. М. Технологічні основи тиражної стабільності друкарських форм / В. М. Скиба; за заг. ред. О. М. Величко [Текст]: моногр. К.: ВПЦ «Київський університет», 2015. 148 с. 
16. Зоренко О. В. Основи зносостійкості друкарських форм: навч. посіб. О. В. Зоренко, В. М. Скиба. Київ: КПІ ім. Ігоря Сікорського, 2018. 42 с. URL: https://ela.kpi.ua/handle/123456789/32172.

\section{References}

1. Savchenko, K. I. \& Zorenko, O. V. \& Rozum, T. V. \& Velychko, O. M. (2011). Suchasnyi stan tekhnolohii drukuvannia v Ukraini [The current state of printing technologies in Ukraine]. Journal of Tekhnolohiia i tekhnika drukarstva, 2(32), 21-27. DOI: http://doi.org/10.20535/2077-7264.2(32).2011.52761 [in Ukrainian].

2. Dubina, N. (2019). Glavnye trendy v upakovke: fakty i prognozy [Top packaging trends: facts and forecasts]. Journal of Komp'Art, 2. Retrieved from http://compuart.ru/article/25411 [in Russian].

3. (2020). Gibkaya upakovka: plyusov poka bol'she, chem minusov, sootvetstvenno, i rost neizbezhen [Flexible packaging: so far there are more advantages than disadvantages, respectively, and growth is inevitable]. Retrieved from http://printus.com.ua/article/read/4152 [in Russian].

4. (2018). Sovremennye tendentsii v gibkoy upakovke [Current trends in flexible packaging]. MacHouse. Retrieved from https://machouse.ua/press-center/ s3/publications/covremennye-tendentsii-v-hibkoj-upakovke.html [in Russian].

5. Stefanyshena, O. B. \& Zorenko, O. V. (2020). Suchasni tendentsii rozvytku hlybokoho druku [Current trends in the development of intaglio printing]. Tekhnolohiia i tekhnika drukarstva, 3(69, 34-42. DOI: https://doi.org/ 10.20535/2077-7264.3(69).2020.224199 [in Ukrainian].

6. Khokhlova, R. A. Vidpovid polihrafii trendam rozvytku upakovky [The answer of polygraphy to trends in the development of packaging]. Upakovka. Retrieved from http://www.upakjour.com.ua/arx\%D1\%96v/2021/2-2021/pol\%D1\% 96graf\%D1\%96ya/printing-answer [in Ukrainian].

7. Shintaro, S. \& Yoshinobu, S. Gravure cylinder and manufacturing method thereof // Patent 2018093467 USA. Publish 05.04.2018 [in English].

8. Takashi, S. \& Kosuke, M. Device for manufacturing resin coat gravure cylinder, method for manufacturing resin coat gravure cylinder and method for inspecting resin coat layer // Patent 2019171733 Japan. Publish 10.10.2019 [in English].

9. Samarin, Yu. (2011). Vo glubine pechatnykh form... [In the depth of printing forms]. Komp'yuArt, 4. Retrieved from http://compuart.ru/article/22153 [in Russian].

10. Polyanskiy, N. N. \& Kartasheva, O. A. \& Nadirova, E. B. (2010). Tekhnologiya formnikh protsessov [Formal processes technology]. Moscow: MGUP, $366 \mathrm{p}$. [in Russian].

11. Sovremennaya tekhnologiya i oborudovanie glubokoy pechati v proizvodstve upakovochnoy produktsii [Modern technology and equipment for gravure printing in the production of packaging products]. Retrieved from http://docplayer.ru/65181239-sovremennaya-tehnologiya-i-oborudovanieglubokoy-pechati-v-proizvodstve-upakovochnoy-produkcii.html [in Russian].

12. Rozum, T. V. \& Zorenko, Ya. V. \& Savchenko, K. I. \& Skyba, V. M. (2012). Kontrol yakosti drukuvannia na pakovanni [Quality Control of Printing on the Package]. Journal of Upakovka. Zhurnal dlia vyrobnykiv ta spozhyvachiv tary $i$ upakovky, 3, 63-66. Retrieved from http://pvs.uad.Iviv.ua/static/media/157/15.pdf [in Ukrainian]. 
13. Zorenko, O. V. \& Rozum, O. F. (2008). Dekeli v ofsetnomu drukarskomu protsesi [Rubber blankets in the offset printing]. Kyiv: VPTs 'Kyivskyi universytet', 168 p. [in Ukrainian].

14. Zorenko, O. V. \& Havrysh, A. P. (2008). Znosostiikist ofsetnykh humotkanynnykh polotnyshch (vplyv na tyrazhnu yakist vidbytkiv) [Wear resistance of offset rubber blankets (influence on the circulation quality of imprints)]. Upakovka, 4, 56-59 [in Ukrainian].

15. Skyba, V. M. (2015). Tekhnolohichni osnovy tyrazhnoi stabilnosti drukarskykh form [Technological bases of circulation stability of printing forms]. Kyiv: VPTs 'Kyivskyi universytet', 148 p. [in Ukrainian].

16. Zorenko, O. V. \& Skyba, V. M. (2018). Osnovy znosostiikosti drukarskykh form [Fundamentals of wear resistance of printing forms]. Kyiv: KPI im. Ihoria Sikorskoho, 42 p. Retrieved from https://ela.kpi.ua/handle/123456789/32172.

Trends in the production of flexible packaging from polymeric materials by the gravure printing are considered. The zone of printing contact of the gravure printing from the standpoint of tribology, the influence of elements of the tribotechnical system and their properties on the wear resistance of the printing form and the quality of imprints are analyzed. Classifications of form materials, form equipment of gravure printing, tribotechnical model of interaction of elements of system 'printing form of gravure printing-imprint', algorithm of form process and recommendations on increase of gravure plate run length are developed.

Keywords: gravure printing; flexible packaging; gravure plate run length; tribotechnical system; tribological analysis. 